\title{
Sensitivity of mice to lipopolysaccharide is increased by a high saturated fat and cholesterol diet Hong Huang1,3, Tongzheng Liu ${ }^{1}$, Jane L Rose ${ }^{1}$, Rachel L Stevens ${ }^{1}$ and Dale G Hoyt*1,2
}

Address: ${ }^{1}$ Division of Pharmacology, The Ohio State University College of Pharmacy, Columbus, OH, 43210, USA, ${ }^{2}$ The Dorothy M. Davis Heart and Lung Research Institute, Columbus, OH, 43210, USA and ${ }^{3}$ Center for Cardiovascular Medicine, Columbus Children's Research Institute, Columbus, OH, 43205, USA

Email: Hong Huang - huangh@ccri.net; Tongzheng Liu - liu.587@osu.edu; Jane L Rose - rose.847@osu.edu;

Rachel L Stevens - stevens.390@osu.edu; Dale G Hoyt* - hoyt.27@osu.edu

* Corresponding author

Published: 12 November 2007

Journal of Inflammation 2007, 4:22 doi:10.1 I86/1476-9255-4-22
Received: 19 June 2007

Accepted: 12 November 2007

This article is available from: http://www.journal-inflammation.com/content/4/I/22

(C) 2007 Huang et al; licensee BioMed Central Ltd.

This is an Open Access article distributed under the terms of the Creative Commons Attribution License (http://creativecommons.org/licenses/by/2.0), which permits unrestricted use, distribution, and reproduction in any medium, provided the original work is properly cited.

\begin{abstract}
Background: It was hypothesized that a pro-atherogenic, high saturated fat and cholesterol diet (HCD) would increase the inflammatory response to $E$. coli endotoxin (LPS) and increase its concentration in plasma after administration to mice.
\end{abstract}

Methods: C57BI/6 mice were fed a HCD or a control diet (CD) for 4 weeks, and then treated with saline, 0.5 , I or $2 \mathrm{mg}$ LPS $/ \mathrm{kg}$, ip. Liver injury (alanine:2-oxoglutarate aminotransferase and aspartate aminotransferase, collagen staining), circulating cytokines (tumor necrosis factor- $\alpha$, interleukin- 6 and interferon- $\gamma$ ), factors that can bind LPS (serum amyloid A, apolipoprotein AI, LPS binding protein, and CDI4), and plasma levels of LPS were measured. The hepatic response was assessed by measuring vascular cell adhesion molecule (VCAM)-I, inducible nitric oxide synthase (iNOS) and signal transducer and activator of transcription-I proteins, and VCAM-I and iNOS mRNAs. Hepatic mRNA encoding the LPS receptor, Toll like receptor 4, was also determined.

Results: Two mg LPS/kg killed $100 \%$ of mice fed HCD within $5 \mathrm{~d}$, while no mice fed CD died. All mice treated with 0 to $1 \mathrm{mg}$ LPS/kg survived $24 \mathrm{~h}$. HCD increased plasma alanine:2-oxoglutarate aminotransferase and aspartate aminotransferase, and the enzymes were increased more by LPS in HCD than CD mice. Induction of plasma tumor necrosis factor- $\alpha$, interleukin- 6 , and interferon- $\gamma$ by LPS was greater with HCD than CD. Hepatic VCAM-I and iNOS protein and mRNA were induced by LPS more in mice fed HCD than CD. Tyrosine phosphorylation of signal transducer and activator of transcription-I caused by LPS was prolonged in HCD compared with CD mice. Despite the hepatic effects of HCD, diet had no effect on the LPS plasma concentration-time profile. HCD alone did not affect circulating levels of plasma apolipoprotein AI or LPS binding protein. However, plasma concentrations of serum amyloid $A$ and $C D I 4$, and hepatic toll-like receptor-4 mRNA were increased in mice fed HCD.

Conclusion: HCD increased the sensitivity of mice to LPS without affecting its plasma level. Although increased serum amyloid A and CDI4 in the circulation may inhibit LPS actions, their overexpression, along with hepatic toll-like receptor-4 or other factors, may contribute to the heightened sensitivity to LPS. 


\section{Background}

Sepsis is a complex syndrome that results from the host response to infection. Systemic effects of Gram-negative sepsis are mediated in large part by lipopolysaccharide (LPS), which causes tissue injury and inflammation. During bacterial sepsis, as opposed to focal infection or local inflammation, a major organ that responds to LPS is the liver $[1,2]$. LPS induces hepatic production of acute phase proteins, such as C-reactive protein, serum amyloid A (SAA), CD14, and LPS binding protein (LBP), which may actually function to restrict LPS action [3-6].

LPS causes endothelial activation with up-regulation of adhesion molecules, and promotes the release cytokines, including tumor necrosis factor- $\alpha$ (TNF $\alpha$ ), interleukin- 6 (IL-6) and interferon- $\gamma$ (IFN $\gamma$ ), which typically increase in sequence [7-9]. LPS, directly and via cytokines, activates transcription of pro-inflammatory genes such as inducible nitric oxide synthase (iNOS), and vascular cell adhesion molecule-1 (VCAM-1). This results in production of nitric oxide that may contribute to shock and other events, while endothelial VCAM-1 mediates sequestration of leukocytes in tissues [10]. The induction of iNOS and VCAM1 is driven by the activation of several transcription factors, including nuclear factor kappa B (NFkB), activating protein-1 (AP-1) and signal transducer and activator of transcription-1 (STAT1) [11-14].

Genetic and extrinsic factors affect the response to LPS. One extrinsic factor is diet. High dietary cholesterol increased susceptibility to various viral and bacterial infections [15-19]. Dietary cholesterol increased serum amyloid A, histocompatibility class II, TNF $\alpha$ and other inflammatory molecules in response to LPS [20-24], and high fat diet induced histocompatibility class II [25]. Tolllike Receptor 4 (TLR4), which mediates many effects of LPS, was expressed in atherosclerotic lesions [26,27], and aortas of TLR4 knockout mice had reduced inflammatory activation in response to a high fat diet [28], suggesting a role for this endotoxin receptor in these diet-related effects. Dietary fat and cholesterol could also increase responses to LPS by increasing its blood levels after exposure. Given the inflammatory effects of atherogenic diets, and the role of endotoxins in acute and chronic disease $[7,22]$, we hypothesized that a high saturated fat and cholesterol diet (HCD) would increase effects of LPS and its plasma concentration after administration to mice.

\section{Methods}

Female C57BL/6 mice, 3-4 wk old, were purchased from Jackson laboratories, Bar Harbor, ME. Mice were randomly fed the HCD or control diet (CD) (Research Diets, Inc., New Brunswick, NJ, Table 1) for $4 \mathrm{wk}$, when cholesterol reached a steady level in HCD mice (data not shown). Mice were treated with an intraperitoneal (ip) injection of E. coli LPS, serotype 0111:B4 (Sigma-Aldrich, Inc., St. Louis, MO) in sterile saline solution after $4 \mathrm{wk}$ feeding. The protocol was carried out under approval of the Ohio State University Animal Care and Use Committee. In the first experiment, 8 mice per group were treated

Table I: Composition of the purified HCD and CD

\begin{tabular}{|c|c|c|c|c|}
\hline \multirow[b]{2}{*}{$\underline{\text { Ingredient }}$} & \multicolumn{2}{|c|}{$\underline{\mathrm{HCD}(\mathrm{D} \mid 2336)^{\prime}}$} & \multicolumn{2}{|c|}{$\mathrm{CD}(\mathrm{D} \mid 2337)^{\prime}$} \\
\hline & $\mathrm{g} / \mathrm{kg}$ of Diet & $\mathrm{k} / \mathrm{g}$ of Diet & $\mathrm{g} / \mathrm{kg}$ of Diet & $\mathrm{k} / \mathrm{g}$ of Diet \\
\hline Casein, 30 Mesh & 75 & 1.26 & 67 & 1.12 \\
\hline Soy Protein & 130 & 2.18 & 116 & 1.94 \\
\hline DL-Methionine & 2 & 0.03 & 1.8 & 0.03 \\
\hline Corn Starch & 275 & 4.60 & 466 & 7.81 \\
\hline Maltodextrin 10 & 150 & 2.51 & 134 & 2.24 \\
\hline Sucrose & 30 & 0.50 & 27 & 0.45 \\
\hline Cellulose, BW200 & 90 & 0 & 80 & 0 \\
\hline Soybean Oil & 50 & 1.88 & 45 & 1.68 \\
\hline Cocoa Butter & 75 & 2.3 & 0 & 0 \\
\hline Coconut Oil, 76 & 35 & 1.32 & 0 & 0 \\
\hline Mineral Mix SI000I [60] & 35 & 0 & 31.2 & 0 \\
\hline Calcium Carbonate & 5.5 & 0 & 4.9 & 0 \\
\hline Sodium Chloride & 8 & 0 & 7.1 & 0 \\
\hline Potassium Citrate & 10 & 0 & 8.9 & 0 \\
\hline Vitamin Mix VI000I [60] & 10 & 0.17 & 8.9 & 0.15 \\
\hline Choline Bitartrate & 2 & 0 & 1.8 & 0 \\
\hline Cholesterol, USP & 12.5 & 0 & 0.27 & 0 \\
\hline Sodium Cholic Acid & 5 & 0 & 0 & 0 \\
\hline FD\&C Red Dye \#40 & 0.10 & 0 & 0 & 0 \\
\hline FD\&C Blue Dye \#40 & $\underline{0}$ & $\underline{0}$ & 0.09 & $\underline{0}$ \\
\hline Total & 1000 & 16.8 & 1000 & 15.4 \\
\hline
\end{tabular}

'Product Number from Research Diets, Inc. is indicated in parentheses. 
with 0 or $2 \mathrm{mg}$ LPS $/ \mathrm{kg}$, ip. With the unexpected lethality in HCD mice (figure 1), independent groups fed CD or HCD were subsequently treated with of $0,0.5$, or 1.0 LPS $\mathrm{mg} / \mathrm{kg}$. For plasma LPS determinations, pilot experiments indicated that serial sampling of blood from mice produced samples variably contaminated with LPS. Therefore, a single sample of blood was taken from the right ventricle of 5 individual mice in each group. Plasma was recovered and stored at $-80^{\circ} \mathrm{C}$ and livers were removed and frozen in liquid nitrogen.

Plasma cholesterol was measured with Infinity Cholesterol Reagents (Sigma-Aldrich, Inc., St. Louis, MO). Plasma alanine:2-oxoglutarate aminotransferase (ALT), aspartate aminotransferase (AST) were measured with a kinetic assay [29], using reagents from Thermo Trace, Louisville, CO. Limulus amoebocyte lysate chromogenic endpoint assay (Hycult Biotechnology b. v., Norwood, MA) was used for LPS detection [30]. Absorbance was read at $405 \mathrm{~nm}$. To exclude the possibility that lipid levels would affect the sensitivity of the assay, various standard curves with reconstituted LPS diluted in plasma collected from untreated CD or HCD mice. There was no statistical difference between these curves (data not shown).

Plasma samples were diluted with endotoxin-free water and tested with ELISA kits for TNFa, IL-6, and IFN $\gamma$ (BD Bioscience, Pharmagen) and SAA (BioSource International, Camarillo, CA). Wells of plates were coated with

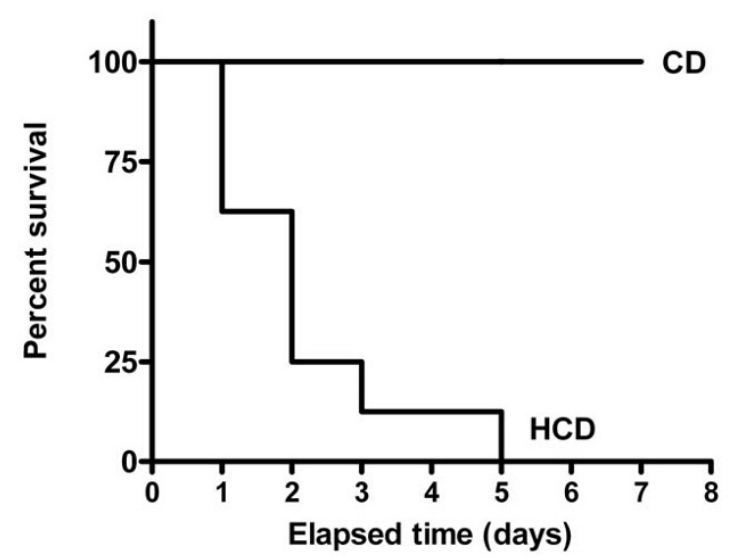

Figure I

The effect of LPS on survival of mice. C57BI/6 mice (8 per group), were fed HCD or CD for $4 \mathrm{wk}$, and then treated with a single dose of LPS ( $2 \mathrm{mg} / \mathrm{kg}$, ip). The median survival time for mice fed HCD was $2 \mathrm{~d}$ and the curves differed significantly $(p<0.000 \mathrm{I})$. primary antibody standards or samples were incubated in the wells, treated with avidin-horseradish peroxidase. 3, 3', 5, 5'-Tetramethyl benzidine was added to develop color. Absorbance was read at $450 \mathrm{~nm}$ after stopping with $1 \mathrm{~mol} / \mathrm{L} \mathrm{H}_{3} \mathrm{PO}_{4}$.

Five ul plasma were also mixed with denaturing sample buffer [11], heated $10 \mathrm{~min}$ at 95 degrees, and subjected to SDS-PAGE and western blotting with anti-mouse apolipoprotein A1 (Abcam, Inc., Cambridge, MA), anti-mouse CD14 (BD Pharmingen, San Diego, CA) or anti-mouse LBP (Cell Sciences, Inc., Canton, MA). Ten mg of liver tissue were lysed in $100 \mu \mathrm{L}$ RIPA buffer (1\% TritonX-100, 50 $\mathrm{mM}$ Tris, $\mathrm{pH}$ 7.5, $150 \mathrm{mmol} / \mathrm{L} \mathrm{NaCl}, 5 \mathrm{mmol} / \mathrm{L}$ EDTA, 0.5 $\mathrm{mmol} / \mathrm{L} \mathrm{Na}_{3} \mathrm{VO}_{4}, 50 \mathrm{mmol} / \mathrm{L} \mathrm{NaF}, 10 \mathrm{mg}$ aprotinin/L, 10 mg leupeptin/L, $10 \mathrm{mg}$ pepstatin $\mathrm{A} / \mathrm{L}$, and $1 \mathrm{mmol} / \mathrm{L}$ PMSF) and sonicated. Protein concentrations were determined [31], and $10 \mu \mathrm{g}$ liver protein was subjected to western blotting [11]. Antibodies used were rabbit antiinducible nitric oxide synthase (iNOS) (Transduction Laboratories, Lexington, KY), goat anti-mouse vascular cell adhesion molecule-1 (VCAM-1) (Santa Cruz Biotechnology, Inc. Santa Cruz, CA), rabbit anti-signal transducer and activator of transcription 1, total (STAT1), and antiphospho-STAT1 (Y701) (Cell Signaling Technology, Inc. Beverly, MA). Horseradish peroxidase-conjugated goat anti-mouse, goat anti-rat, goat anti-rabbit, rabbit anti-goat secondary antibodies (Jackson ImmunoResearch Laboratories, Inc. West Grove, PA) were used to detect labeled proteins with enhanced chemiluminescence and X-ray film exposure. Films were digitally scanned and integrated signal intensity of bands was calculated by image analysis (NIH Image J).

Approximately $50 \mathrm{mg}$ of liver was homogenized in $1 \mathrm{~mL}$ of Trizol reagent, and total cellular RNA was extracted, reverse transcribed into cDNA and subjected to polymerase chain reaction as described previously (primers, reagents and enzymes were from Invitrogen Corporation, Grand Island, NY) [11]. The primers used in this study were: iNOS [GenBank: NM 010927], sense: 5'-CCT GGA CAA GCT GCA TAT GA-3'; antisense: 5'-GCT GTG TGG TGG TCC ATG AT-3'; VCAM-1 [GenBank: NM 011693], sense: 5'-GCG CTG TGA CCT GTC TGC AA-3' and antisense: 5'-GGT GTA CGG CCA TCC ACA G-3'; TLR4 [GenBank: AF185285], sense: 5'-GCT TAC ACC ACC TCT CAA ACT TGA T-3', antisense: 5'-ATT ACC TCT TAG AGT CAG TTC ATG G-3'; $\beta$-actin [GenBank: $\underline{\text { X03672] }}$, sense: 5'-ATG GAT GAC GAT ATC GCT-3', antisense: 5'-ATG AGG TAG TCT GCT AGG T-3'. The polymerase chain reaction conditions included an initial denaturation at $94^{\circ} \mathrm{C}$ for $5 \mathrm{~min}$, followed by a cycle of denaturation $\left(94^{\circ} \mathrm{C} / 1 \mathrm{~min}\right)$, annealing $\left(1 \mathrm{~min}\right.$ at $60^{\circ} \mathrm{C}$ for iNOS and $\beta$-actin, or at $55^{\circ} \mathrm{C}$ for VCAM- 1 and TLR4), and extension $\left(72^{\circ} \mathrm{C} / 1\right.$ $\mathrm{min})$. Each sample was subjected to 35 cycles followed by 
a final extension $\left(72^{\circ} \mathrm{C}\right.$ for $\left.10 \mathrm{~min}\right)$. Equal amounts of RNA, determined by absorbance at $260 \mathrm{~nm}$, were reverse transcribed. Polymerase chain reaction products were separated and visualized on a $1.0 \%$ agarose ethidium bromide stained gel. Band intensity was assessed from digital images with analysis software (UVP-Labworks Analysis), normalized to $\beta$-actin expression in each sample. The densitometric ratio of target mRNA signal to $\beta$-actin signal was calculated.

Hepatic fibrosis was evaluated in formalin-fixed, paraffinembedded tissues using Masson's trichrome stain (SigmaAldrich, Inc., St. Louis, MO) [32]. Images were captured using a $20 \times$ objective on a standard upright microscope (Olympus, Melville, NY) and a digital camera (Diagnostic Instruments, Sterling Heights, MI). Five images were captured per section from 5 mice fed CD or HCD. Blue collagen staining was defined, and the extent of fibrosis, as a percentage of total tissue area in each image, was calculated using Image Pro Plus image analysis software (Media Cybernetics, Silver Springs, MD).

Survival was analyzed by the Mantel-Haenszel test. Other data were analyzed by Student's t-test or by ANOVA with Bonferroni adjustment for multiple comparisons of independent groups [33]. A p-value less than 0.05 was considered significant.

\section{Results}

Plasma cholesterol was increased by 4 wk feeding HCD in comparison with CD (means \pm SE were $3.3 \pm 0.02$ in CD mice and $5.3 \pm 0.02 \mathrm{mmol} / \mathrm{L}$ in HCD mice, $\mathrm{p}<0.0001$ ). Body weights did not differ between mice fed the CD $(23.37 \pm 0.04 \mathrm{~g})$ and HCD $(23.42 \pm 0.04 \mathrm{~g})$. Food intake over 4 wk did not differ between the groups $(1.9 \pm 0.19 \mathrm{vs}$. $1.8 \pm 0.17 \mathrm{~g} /$ mouse $/ \mathrm{d}$ for $\mathrm{CD}$ and HCD), and energy intake was not different $(30.5 \pm 2.8$ and $31.9 \pm 2.9 \mathrm{~kJ} /$ mouse/d in mice fed CD and HCD respectively). These results are similar to those of others using similar diets with $\mathrm{C} 57 \mathrm{Bl} / 6$ mice [34]. Liver weights were significantly increased in HCD as compared with CD mice: liver to body weight ratio was $4.15 \pm 0.005 \%$ in mice fed the CD and $6.37 \pm 0.012 \%$ in mice fed the HCD $(\mathrm{p}<0.0001)$.

C57BL/6 mice fed HCD were extremely sensitive to LPS: after a single ip dose of $2 \mathrm{mg} / \mathrm{kg}$ none of the mice survived for $5 \mathrm{~d}$, compared with a $100 \%$ survival in the CD group (Figure 1). The median survival time for mice fed HCD was $2 \mathrm{~d}$ and the curves differed significantly $(\mathrm{p}<0.0001)$. Therefore, lower doses of LPS ( 0.5 to $1 \mathrm{mg} / \mathrm{kg}$ ) were used for subsequent experiments. Plasma ALT and AST activities were elevated in saline-treated mice fed the HCD in comparison with $\mathrm{CD}$, and were further elevated only in HCD mice $12 \mathrm{~h}$ after LPS treatment (figure 2). The extent of fibrosis, indicated by the relative area of collagen stain-
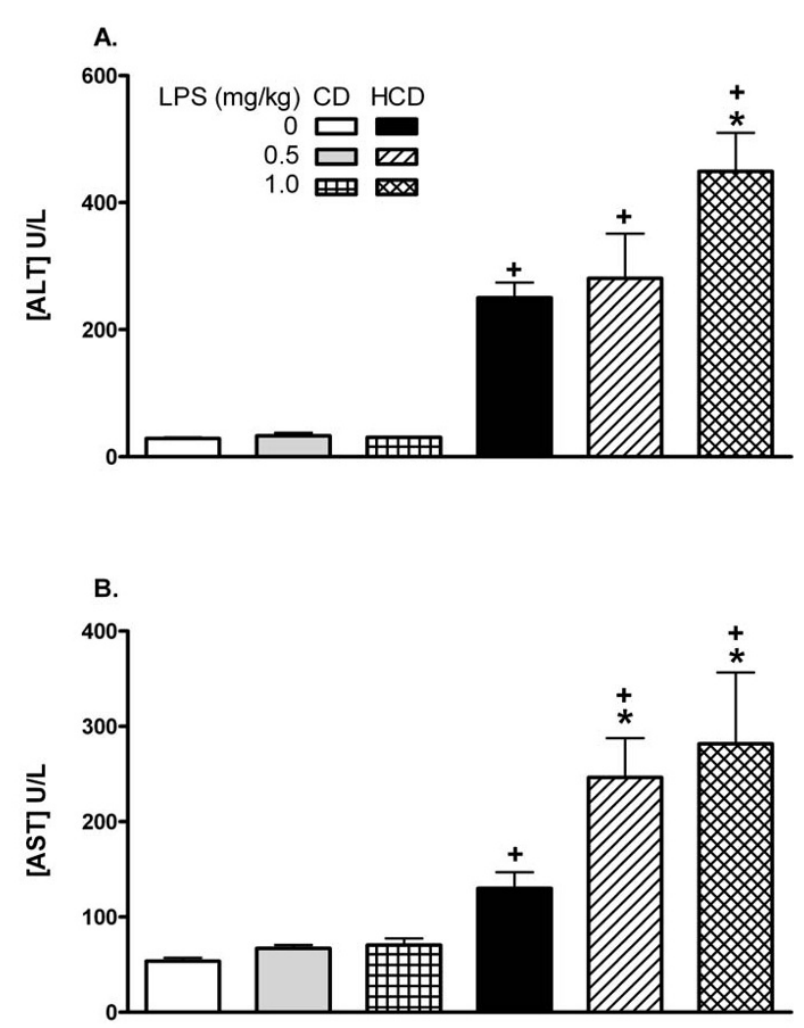

Figure 2

The effect of diet on plasma ALT and AST. CD or HCD mice received a single ip injection of $0,0.5$, or $1.0 \mathrm{mg} \mathrm{LPS} / \mathrm{kg}$ and blood was sampled after $12 \mathrm{~h}$. Values are mean + SE of 5 mice per group. *: $p<0.05$ for comparison with $0 \mathrm{mg}$ LPS $/ \mathrm{kg}$. $+: p<0.05$ for comparison with CD mice treated with the same dose of LPS.

ing in liver sections, was not affected by diet (relative areas were $0.057 \pm 0.017$ in $\mathrm{CD}$ and $0.076 \pm 0.054$ in HCD sections).

The effect of HCD on plasma cytokines that mediate some effects of LPS was determined. Plasma TNF $\alpha$ was elevated only in CD mice treated with $1 \mathrm{mg}$ LPS/ $\mathrm{kg}$ at $2 \mathrm{~h}$, while increases were significantly greater in LPS-treated HCD mice (Figure 3A). IL-6 and IFN $\gamma$ were also significantly increased by LPS, and the increases were greater in HCD mice compared with CD (Figure 3B and 3C). In particular, IL-6 remained elevated for at least $12 \mathrm{~h}$ in HCD mice and the typically delayed increase in IFN $\gamma$ was observed $12 \mathrm{~h}$ after LPS only in HCD mice.

Hepatic VCAM-1 mRNA was induced $0.5 \mathrm{~h}$ after LPS injection with respect to the saline-treated mice in both diet groups, but was increased more in the HCD mice (Figure 
mRNA signal was increased by LPS in HCD mice with a peak at $2 \mathrm{~h}$ (Figure 5A). iNOS protein was increased in

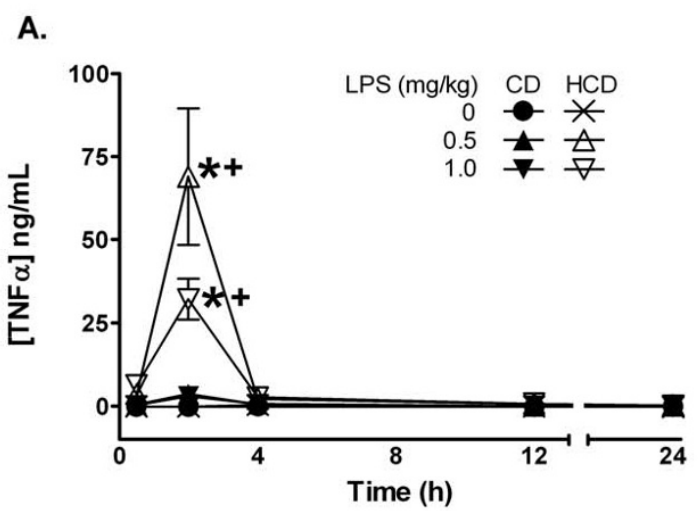

B.

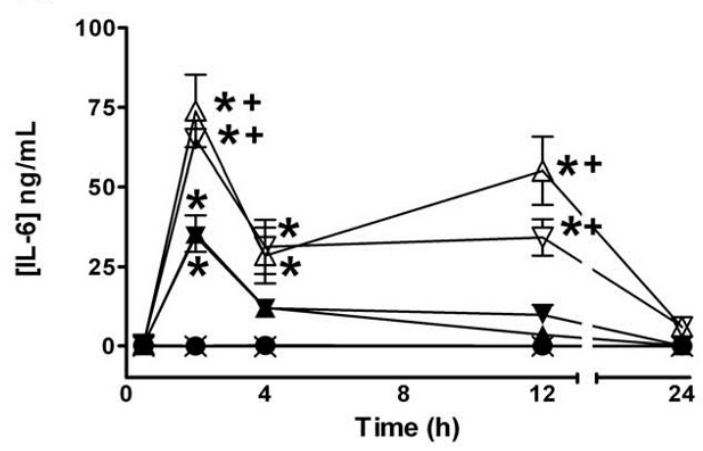

C.

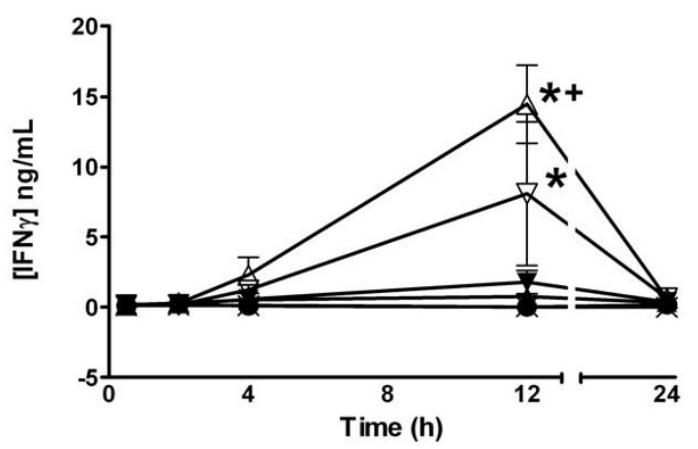

Figure 3

The effect of diet and LPS on plasma levels of pro-inflammatory TNF $\alpha(A)$, IL-6 (B), and IFN $\gamma(\mathrm{C})$. Plasma levels were measured $0.5,2,4,12$, or $24 \mathrm{~h}$ after treatment. Values are the mean \pm SE of 5 mice per group. *: $p<0.05$ for comparison with $0 \mathrm{mg}$ LPS $/ \mathrm{kg}$. +: $\mathrm{p}<0.05$ for comparison with $C D$ treated with the same dose of LPS.

4A). Induction reached a peak at 2-4 h and declined over $24 \mathrm{~h}$. While VCAM-1 protein was not increased by LPS in CD mice, it was significantly elevated in HCD mice $4 \mathrm{~h}$ after administration of 0.5 or $1 \mathrm{mg} \mathrm{LPS} / \mathrm{kg}$, and remained elevated $12 \mathrm{~h}$ after $1 \mathrm{mg}$ LPS/kg (Figure 4B). The iNOS

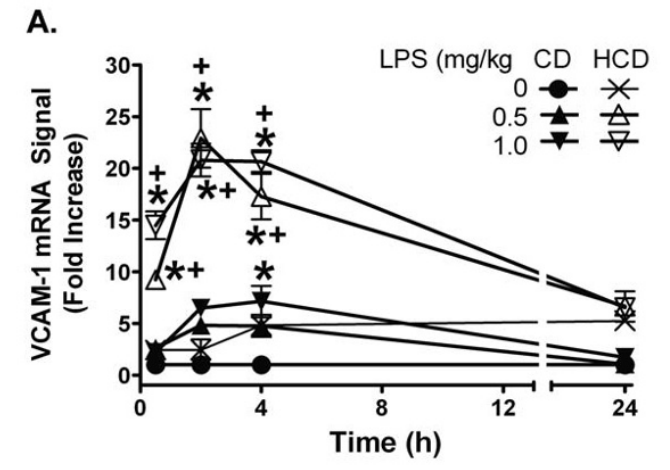

B.
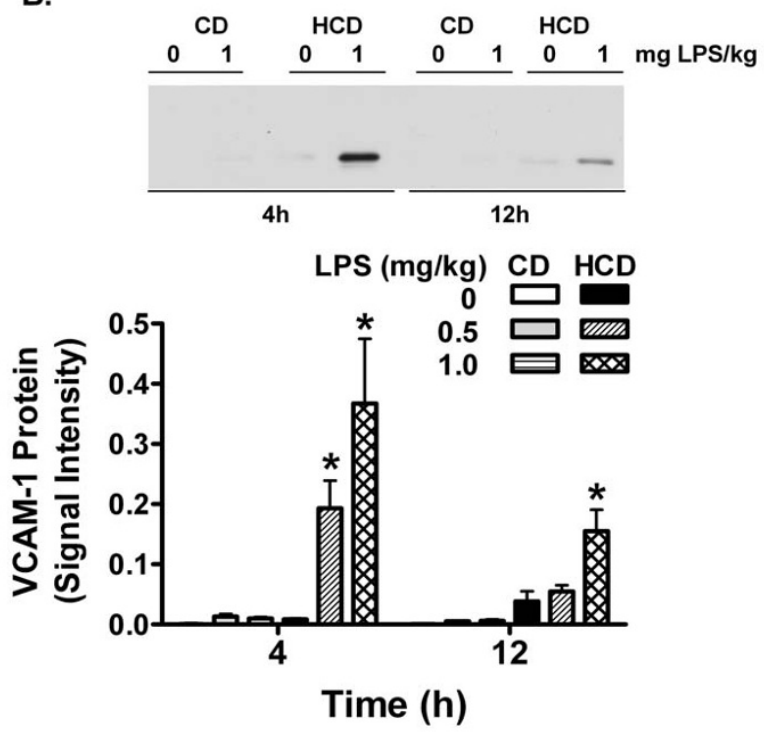

Figure 4

The effect of diet and LPS on hepatic VCAM-I expression. mRNA levels $(A)$ were measured with RT-PCR. Densitometric intensity of images of ethidium bromide-stained agarose gels were normalized to $\beta$-actin RT-PCR signal. Induction of VCAM-I RT-PCR signal ratios ( $\mathrm{n}=5$ in each group) are expressed as fold increase compared to vehicle-treated $C D$ mice, represented by I on the $y$-axis. Values are expressed mean \pm SE of 5 mice are the fold increases in VCAM-I/ $\beta$ actin mRNA signal ratio relative CD mice treated with $0 \mathrm{mg}$ $\mathrm{LPS} / \mathrm{ml}$ (represented by I on the y-axis). The level of VCAMI protein (B) was measured by western blotting 4 and $12 \mathrm{~h}$ after treatment (representative images and image analysis). Values are the mean + SE of total integrated signal intensity obtained from densitometry for 5 mice in each group. *: $p<$ 0.05 for comparison with $0 \mathrm{mg}$ LPS $/ \mathrm{kg}$. +: $\mathrm{p}<0.05$ for comparison with CD treated with the same dose of LPS. 
HCD mice $12 \mathrm{~h}$ after 0.5 and $1 \mathrm{mg} \mathrm{LPS} / \mathrm{kg}$, and not in CD mice (Figure 5B).

IL-6 and IFN $\gamma$ cause inflammatory gene expression in part by activating STAT1 $[11,35]$. Total levels of STAT1 $\alpha$ were increased in HCD and CD mice $12 \mathrm{~h}$ after treatment with LPS in comparison with saline (Figure 6A, B). The activated form of STAT1 $\alpha$, phosphorylated at tyrosine 701 (pY701), was increased $4 \mathrm{~h}$ after treatment with LPS, in

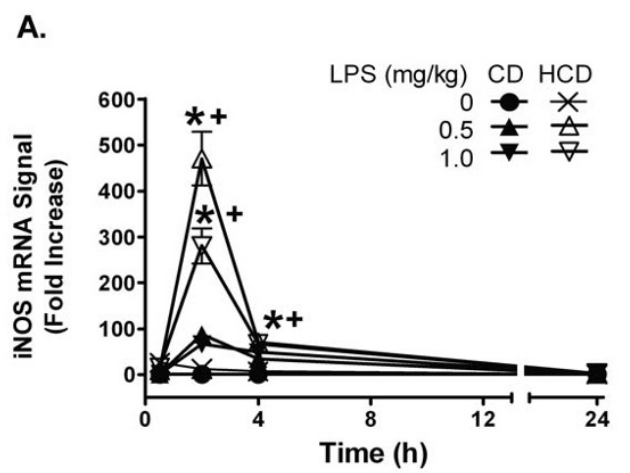

B.

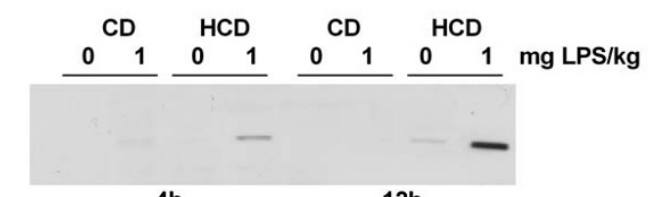

4h

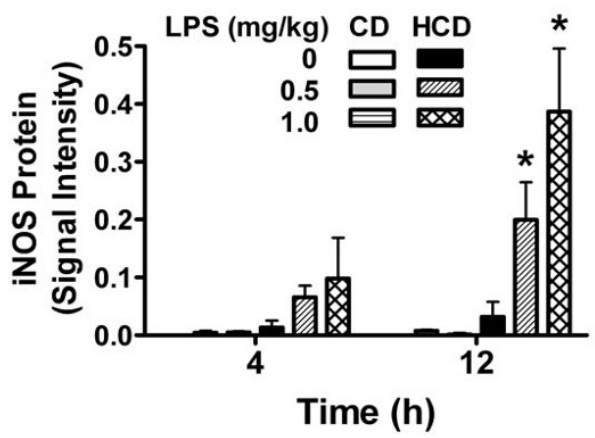

\section{Figure 5}

The effect of diet and LPS on hepatic iNOS expression. iNOS mRNA (A) was assessed as in figure 4. Values are expressed mean \pm SE of 5 mice are the fold increases in iNOS/ $\beta$-actin mRNA signal ratio relative CD mice treated with $0 \mathrm{mg}$ LPS/ $\mathrm{ml}$, represented by I on the $y$-axis. The level of iNOS protein (B) was measured by western blotting 4 and $12 \mathrm{~h}$ after treatment (representative images and image analysis). Values are the mean $+\mathrm{SE}$ of total integrated signal intensity obtained from densitometry for 5 mice in each group. *: $p<0.05$ for comparison with $0 \mathrm{mg}$ LPS $/ \mathrm{kg}$. +: $\mathrm{p}<0.05$ for comparison with CD treated with the same dose of LPS. comparison with saline, in both CD and HCD mice. However, elevated phosphorylation was maintained for $12 \mathrm{~h}$ in LPS-treated HCD mice, while it had decreased in the CD group (Figure 6A, C).

Given the heightened response to LPS, the effect of diet on its plasma levels was determined. LPS was not detectable in blood of saline-treated CD or HCD mice. LPS increased rapidly in plasma after ip injection in both CD and HCD mice (Figure 7). The highest LPS levels occurred at $2 \mathrm{~h}$, and then decreased. There was no difference between mice fed the two diets, except with $1 \mathrm{mg}$ LPS/kg at $24 \mathrm{~h}$, where the level was elevated in CD mice. In another group of mice treated with $1 \mathrm{mg} \mathrm{LPS} / \mathrm{kg}$, plasma LPS was undetect-

A.

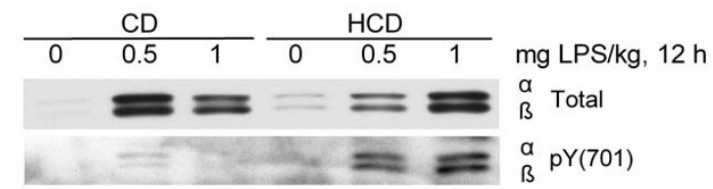

B. LPS $(\mathrm{mg} / \mathrm{kg}) \mathrm{CD} \quad \mathrm{HCD}$

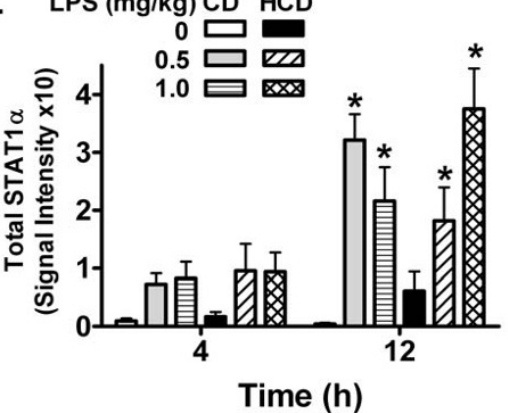

C.

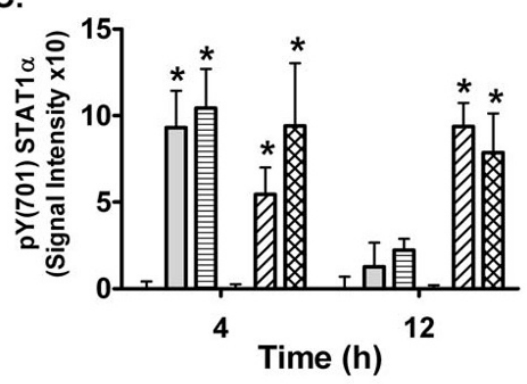

\section{Figure 6}

The effect of diet and LPS on STATI activation in liver. Total and tyrosine 70I phosphorylated (PY70I) STATI protein levels in hepatic tissues from CD and HCD mice were measured by western blotting. A representative image from samples $12 \mathrm{~h}$ after LPS treatment is shown in panel A. STATI $\alpha$ and the shorter $\beta$ form are visible. Densitometric intensity of total and PY70I STATI $\alpha$ was measured and means + SE of 5 mice fed each diet 4 and $12 \mathrm{~h}$ after treatment were calculated (B and $C)$. *: $p<0.05$ for comparison with $0 \mathrm{mg}$ LPS $/ \mathrm{kg}$. 


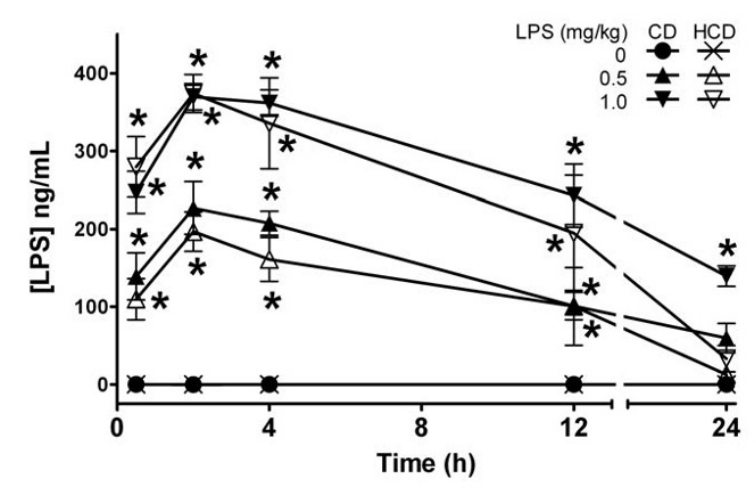

Figure 7

The effect of diet on plasma pharmacokinetics of LPS. CD or HCD mice received a single ip injection of $0,0.5$, or $1.0 \mathrm{mg}$ LPS $/ \mathrm{kg}$. Values are mean \pm SE of 5 mice per group. *: $p<0.05$ for comparison with $0 \mathrm{mg}$ LPS/kg for each diet.

able $7 \mathrm{~d}$ after treatment (data not shown). The half-life for LPS was approximately $12 \mathrm{~h}$, which is similar to results reported in $\mathrm{C} 3 \mathrm{H} / \mathrm{St}$ and $\mathrm{C} 3 \mathrm{H} / \mathrm{HeJ}$ mice [36].

The effect of diet on proteins known to bind LPS was investigated. Plasma SAA was increased 84-fold in HCD compared with CD mice (mean \pm SE was $1.5 \pm 0.9 \mu \mathrm{g} / \mathrm{ml}$ in mice fed the CD, and $126.7 \pm 23.9 \mu \mathrm{g} / \mathrm{ml}$ in mice fed HCD, $\mathrm{p}<0.0001)$. Twelve $\mathrm{h}$ after treatment with $0.5 \mathrm{mg}$ $\mathrm{LPS} / \mathrm{kg}$, SAA was $3912 \pm 821 \mu \mathrm{g} / \mathrm{ml}$ in CD and $5424 \pm 628$ $\mu \mathrm{g} / \mathrm{ml}$ in HCD mice. Plasma CD14 $\mathrm{w}$ as increased 4.1 -fold in HCD compared with CD mice (figure 8A). Plasma LBP and ApoA1, however, were unaffected by diet (Figure $8 \mathrm{~B}$, C). Finally, reverse transcription-polymerase chain reaction (RT-PCR) products of TLR4 mRNA were increased in livers of mice fed HCD in comparison with CD mice (Figure 9). Although it would be desirable to assess hepatic TLR4 in mouse liver, several commercially available antibodies identified multiple bands of varying size on western blots of murine samples (not shown).

\section{Discussion}

Feeding HCD for $4 \mathrm{wk}$ raised cholesterol levels and increased the lethal and inflammatory effects of LPS. While there was no evidence of hepatic fibrosis, mild increases in plasma ALT and AST suggested that HCD alone affected the liver. The effect of LPS on these enzymes was also increased in HCD mice. The livers of HCD mice reacted normally to LPS in 2 respects. As detailed later, removal of LPS from plasma was not affected by diet, and, while the plasma SAA was increased by HCD alone, the level to which it was induced by LPS was similar to the
A.

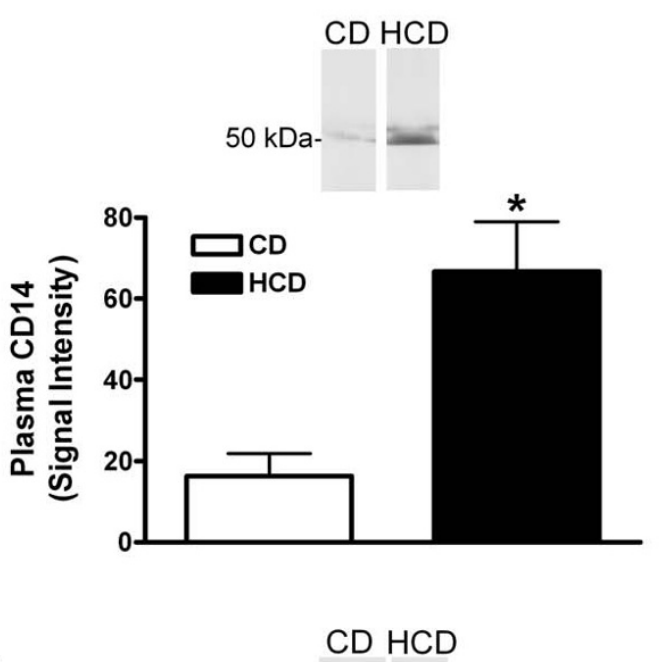

B.
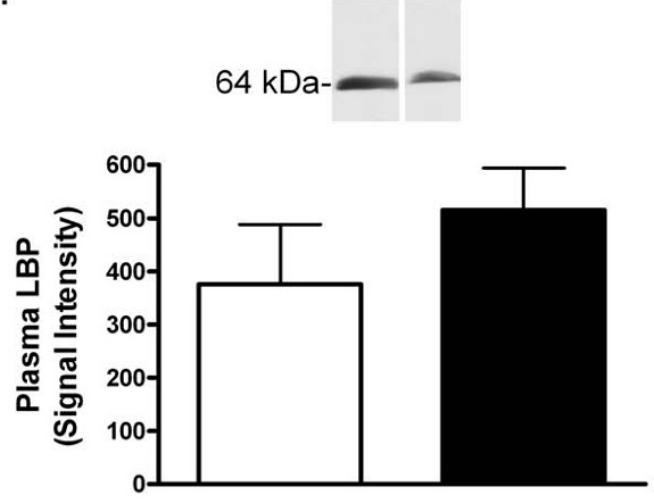

C.
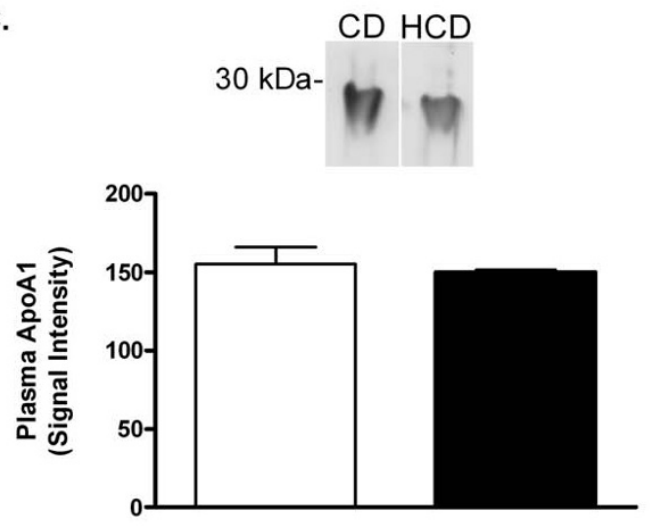

\section{Figure 8}

The effect of diet on plasma CDI4, ApoAI and LBP. CDI4 $(A)$, LBP (B), and ApoAI (C) were measured by densitometry after western blotting of plasma samples from mice fed CD or HCD for 4 weeks. Representative blots are shown. Bars depict the mean + SE for 5 mice in each group. *: $p<$ 0.05 for comparison with CD mice. 

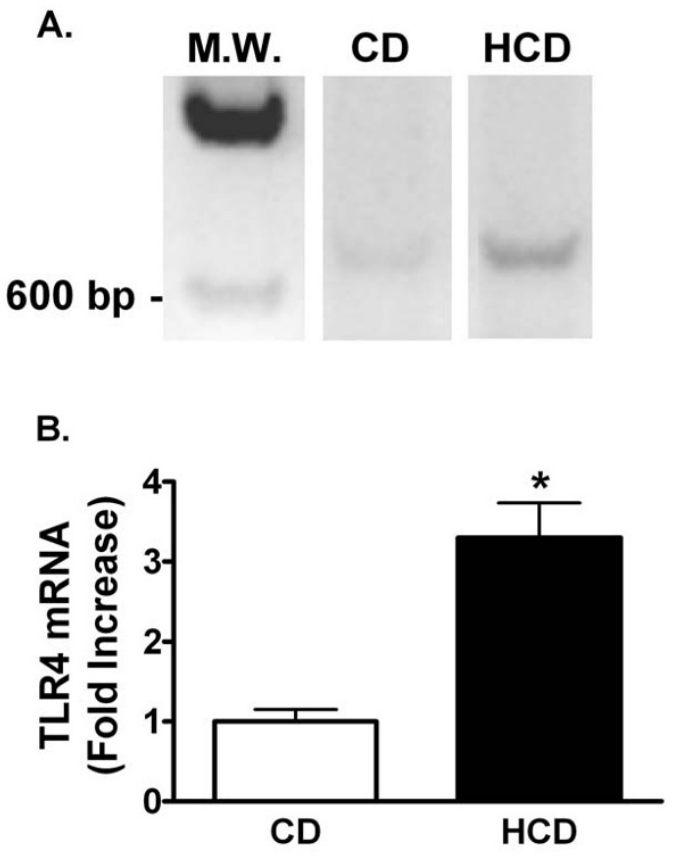

\section{Figure 9}

The effect of diet and LPS on hepatic TLR4 mRNA. Representative images of ethidium-stained agarose electrophoresis gels of RT-PCR products of RNA extracted from livers of mice fed CD or HCD for 4 weeks (A). MW is a Lambda Hindlll molecular weight marker. Signal intensities were measured as in figure $4 A$ and normalized to the RT-PCR signal for $\beta$-actin in each sample (B). Bars depict mean normalized signal ratios + SE for 5 mice fed each diet, relative to the $C D$ group, represented by I on the $y$-axis. *: $p<0.05$ for comparison with $C D$.

induction in CD mice. Further clarification of the role of the liver alteration in sensitivity to LPS is necessary.

Cytokines induced by LPS may mediate its deleterious effects [9]. IFN $\gamma$ for example causes LPS hypersensitivity [37] and promotes atherosclerosis [38]. Although HCD alone did not elevate plasma TNFa, IL-6 or IFN $\gamma$, the higher sensitivity of HCD mice to LPS was paralleled by greater increases in these cytokines in response to LPS in comparison with CD mice (figure 3 ). The observed pattern of a transient spike in TNFa with increased IL-6, which is known to repress TNF $\alpha$ [39], followed by production of IFN $\gamma$, likely from secondarily activated T and B lymphocytes, is a typical response to LPS [9]. Thus, HCD apparently potentiated the cytokine-inducing effects of LPS without qualitatively altering their sequence of appearance. Others found that hypercholesterolemia increased the induction of plasma TNF $\alpha$, or of aortic interleukin- 1 and TNF $\alpha$ mRNA by gram negative endotoxins $[22,24]$. Interestingly, a high fat diet in rats, or familial hypercholesterolemia in humans, did not increase TNF $\alpha$ production by isolated monocytes or whole blood treated with LPS in vitro [40,41]. This suggests that cells in these preparations were not made hyper-responsive to LPS by these conditions. TNF $\alpha$ is constitutively synthesized by Kupffer cells in liver, which rapidly release it after challenge with LPS. While IL-6 is not constitutively expressed, it is rapidly transcribed by these liver macrophages [9]. HCD may increase the sensitivity and/or numbers of circulating leukocytes, and hepatic Kupffer or other cells that could contribute to cytokine production $[42,43]$. Nonhepatic tissues may also be sensitized in vivo [24]. Nevertheless, significant increases in hepatic TLR4 mRNA in untreated HCD mice compared with CD mice support the idea that the liver is made hyper-responsive to LPS by HCD (figure 9).

VCAM-1 and iNOS were measured since they are part of an inflammatory cascade induced by LPS. VCAM-1 mediates localization of various inflammatory cells in tissues. iNOS, on the other hand, can produce large amounts of nitric oxide, a potent vasodilator that may contribute to shock [10]. HCD increased the effect of LPS on hepatic VCAM- 1 and iNOS mRNA and protein (Figures 4 and 5), further confirming the pro-inflammatory nature of HCD.

The murine VCAM- 1 and iNOS promoters are activated by AP-1, NFkB, and by STAT1 and its secondary target, interferon regulatory factor- $1[12-14,44]$. TNF $\alpha$ is a strong activator of AP-1 and NFkB, and IL-6 and IFN $\gamma$ each cause phosphorylation of STAT1 on tyrosine 701, dimerization, and translocation to the nucleus $[11,35,45]$. Thus, early induction of VCAM-1 and iNOS mRNA by LPS may result from actions of LPS or the induced TNF $\alpha$ and IL- 6 on these transcription factors. The prolonged increase in IL- 6 and enhancement of later increases in IFN $\gamma$ by LPS in HCD mice correlates with the extended duration of STAT1 activation (figure 6). While STAT1 may contribute to acute increases in hepatic iNOS and VCAM-1 mRNA, it cannot be the only factor, since it was similarly activated in both $\mathrm{CD}$ and HCD mice $4 \mathrm{~h}$ after LPS treatment. However, the extended duration of STAT1 activation in HCD mice may stimulate the delayed expression of other factors. As seen in cardiac myocytes [44], iNOS protein increased well after mRNA levels peaked and returned to baseline (figure $5)$, suggesting that translation may be increased, or that protein degradation may be reduced in HCD mice at later times after LPS treatment. The role of LPS, TNF $\alpha$, IL-6, IFN $\gamma$, or STAT1 in particular, in the translation or turnover of iNOS and VCAM-1 after HCD remains to be investigated. In any case, inflammatory enhancement by HCD 
may contribute to a detrimental interaction between diet and LPS in vivo.

HCD could increase plasma levels of LPS or its activity. Regardless of diet, however, LPS appeared in the systemic circulation within $30 \mathrm{~min}$ and reached similar peaks 2-4 $\mathrm{h}$ after ip injection (Figure 7). The entire pharmacokinetic profile of LPS was similar in CD and HCD mice, indicating that the hypersensitivity of HCD mice was not due to increased absorption or reduced excretion. If the mild increase in ALT and AST indicates hepatic damage in HCD mice, it was apparently of no consequence for plasma pharmacokinetics of LPS, even though it is excreted in bile [46].

Circulating LPS is carried by LPS-binding proteins and lipoproteins, particularly HDL [3,47-50]. Binding of LPS to lipoproteins inactivates LPS in vitro and in vivo, and reconstituted HDL is anti-inflammatory in animal and human endotoxemia [50-55]. Apolipoproteins themselves appear to be anti-inflammatory and can bind LPS $[3,56]$. The main apolipoprotein of normal HDL is ApoA1, but SAA and the LPS-interacting proteins, LBP and CD14, associate with HDL when they are induced $[3,57]$. In the present investigation, plasma levels of LBP and ApoA1 were not affected by HCD (Figure $8 \mathrm{~B}$ and $8 \mathrm{C}$ ). However, HCD increased plasma SAA as seen by others [20], and plasma CD14 was induced (Figure 8A).

Although the consequences of the increases in SAA and CD14 by HCD for a balance between pro- and antiinflammatory actions of HDL are not known, a number of recent studies suggest that the effects of LPS should be reduced. SAA-HDL and normal HDL equally inhibited the induction of VCAM-1 by TNFa in endothelial cells [58]. However, SAA may also act indirectly to inhibit responses to LPS in vivo. For example, LBP, at concentrations normally found in plasma, antagonized the induction of TNFa by LPS in THP-1 cells in vitro. HDL purified from normal serum prevented this antagonism by LBP more effectively than HDL from critically ill subjects [59]. Since SAA, and probably SAA-HDL, was elevated in these patients, normal HDL may be a more effective antagonist of the anti-inflammatory effects of LBP than SAA-HDL. Thus, a net suppression of LPS activity might be expected when SAA is increased as it was in HCD mice. Although some CD14 is necessary for full activity of LPS at TLR4 receptors, elevated CD14 also antagonizes LPS [6]. If the net effect of elevated plasma SAA and CD14 is to inhibit LPS action, then the observed hypersensitivity of HCD mice may be due to a heightened response of target tissues. Increased hepatic TLR4 mRNA may again be significant in this respect. Further investigation is necessary to determine whether HCD alters the association of LPS with plasma lipoproteins, and whether changes in SAA, CD14 or other circulating factors affect the activity of LPS or its concentration in tissues.

\section{Conclusion}

C57BL/6 mice developed hypercholesterolemia on a $4 \mathrm{wk}$ HCD, accompanied by an inflammatory state with increased SAA and CD14. HCD caused an exaggerated response to LPS without affecting its plasma pharmacokinetics. Effects of HCD on liver, indicated by circulating liver enzymes and TLR4 mRNA, may contribute to the increased sensitivity to LPS. The results demonstrate that dietary cholesterol/fat can significantly affect the severity of the response to endotoxin.

\section{List of abbreviations}

L-alanine:2-oxoglutarate aminotransferase, ALT

aspartateaminotransferase, AST

control diet, $\mathrm{CD}$

high saturated fat and cholesterol diet, HCD

high density lipoprotein, HDL

inducible nitric oxide synthase, iNOS

interleukin-6, IL-6

interferon- $\gamma$, IFN $\gamma$

intraperitoneal, ip

lipopolysaccharide, LPS

lipopolysaccharide binding protein, LBP

nitric oxide, $\mathrm{NO}$

phosphorylated at tyrosine 701, pY701

reverse transcription-polymerase chain reaction, RT-PCR

serum amyloid A, SAA

signal transducer and activator of transcription-1, STAT1

Toll-like receptor-4, TLR4

tumor necrosis factor- $\alpha$, TNF $\alpha$

vascular cell adhesion molecule -1, VCAM-1 


\section{Competing interests}

The author(s) declare that they have no competing interests.

\section{Authors' contributions}

$\mathrm{HH}$ designed the study, and collected results in figures 1 , 2, 3, 4, 5, 6, 7 and 9, measured cholesterol levels and serum amyloid, assessed liver histology, and drafted the manuscript. TL collected the results of figure 8 and contributed to the sections describing and discussing the results. RLS and JLR participated in processing mice and samples, western blotting and RT-PCR for VCAM-1 and iNOS, and contributed to the sections describing and discussing those results. DGH conceived and designed the study, aided in collection of results of figures $1,2,3,4,5$, 6, 7 and 9, and processing of mice, and was the main author and editor of the manuscript. All authors read and approved the final manuscript.

\section{Acknowledgements}

This work was supported by a postdoctoral fellowship 05253 I8B from the American Heart Association, Ohio Valley Affiliate $(\mathrm{HH})$.

\section{References}

I. Darlington GJ, Wilson DR, Revel M, Kelly JH: Response of liver genes to acute phase mediators. Ann N Y Acad Sci 1989, 557:310-5; discussion 315-6.

2. Shimada H, Hasegawa N, Koh H, Tasaka S, Shimizu M, Yamada W, Nishimura T, Amakawa K, Kohno M, Sawafuji M, Nakamura K, Fujishima S, Yamaguchi K, Ishizaka A: Effects of initial passage of endotoxin through the liver on the extent of acute lung injury in a rat model. Shock 2006, 26:31 I-3I5.

3. Berbee JF, Havekes LM, Rensen PC: Apolipoproteins modulate the inflammatory response to lipopolysaccharide. J Endotoxin Res 2005, I I:97-103.

4. Kitchens RL, Thompson PA, Viriyakosol S, O'Keefe GE, Munford RS: Plasma CDI4 decreases monocyte responses to LPS by transferring cell-bound LPS to plasma lipoproteins. J Clin Invest 200I, I08:485-493.

5. Kitchens RL, Thompson PA: Impact of sepsis-induced changes in plasma on LPS interactions with monocytes and plasma lipoproteins: roles of soluble CDI4, LBP, and acute phase lipoproteins. J Endotoxin Res 2003, 9:1।3-118.

6. Kitchens RL, Thompson PA: Modulatory effects of sCDI4 and LBP on LPS-host cell interactions. J Endotoxin Res 2005, I I:225-229.

7. Tracey KJ, Lowry SF: The role of cytokine mediators in septic shock. Adv Surg 1990, 23:21-56.

8. Steel DM, Whitehead AS: The major acute phase reactants: Creactive protein, serum amyloid $P$ component and serum amyloid A protein. Immunol Today 1994, I 5:8|-88.

9. Van Amersfoort ES, Van Berkel TJ, Kuiper J: Receptors, mediators, and mechanisms involved in bacterial sepsis and septic shock. Clin Microbiol Rev 2003, I6:379-4I4.

10. Vincent JL, Zhang H, Szabo C, Preiser JC: Effects of nitric oxide in septic shock. Am J Respir Crit Care Med 2000, I 6 I: I 78 I- I 785.

II. Huang H, Rose JL, Hoyt DG: p38 Mitogen-activated protein kinase mediates synergistic induction of inducible nitricoxide synthase by lipopolysaccharide and interferon-gamma through signal transducer and activator of transcription I Ser727 phosphorylation in murine aortic endothelial cells. Mol Pharmacol 2004, 66:302-3II.

12. Xie QW, Whisnant R, Nathan C: Promoter of the mouse gene encoding calcium-independent nitric oxide synthase confers inducibility by interferon gamma and bacterial lipopolysaccharide. J Exp Med 1993, I77:I779- I784.

13. Deshpande R, Khalili H, Pergolizzi RG, Michael SD, Chang MD: Estradiol down-regulates LPS-induced cytokine production and
NFkB activation in murine macrophages. Am J Reprod Immunol 1997, 38:46-54.

14. Korenaga R, Ando J, Kosaki K, Isshiki M, Takada Y, Kamiya A: Negative transcriptional regulation of the VCAM-I gene by fluid shear stress in murine endothelial cells. Am J Physiol 1997, 273:CI506-15.

15. Kos WL, Loria RM, Snodgrass MJ, Cohen D, Thorpe TG, Kaplan AM: Inhibition of host resistance by nutritional hypercholesteremia. Infect Immun 1979, 26:658-667.

16. Fiser RH Jr., Denniston JC, McGann VG, Kaplan J, Alder WH 3rd, Kastello MD, Beisel WR: Altered immune function in hypercholesterolemic monkeys. Infect Immun 1973, 8: I05-109.

17. Klurfeld DM, Allison MJ, Gerszten E, Dalton HP: Alterations of host defenses paralleling cholesterol-induced atherogenesis. I. Interactions of prolonged experimental hypercholesterolemia and infections. J Med 1979, 10:35-48.

18. Anonymous: Alterations of host defenses paralleling cholesterol-induced atherogenesis. II. Immunologic studies of rabbits. J Med 1979, 1 0:49-64.

19. Pereira CA, Steffan AM, Koehren F, Douglas CR, Kirn A: Increased susceptibility of mice to MHV 3 infection induced by hypercholesterolemic diet: impairment of Kupffer cell function. Immunobiology 1987, I 74:253-265.

20. Vergnes L, Phan J, Strauss M, Tafuri S, Reue K: Cholesterol and cholate components of an atherogenic diet induce distinct stages of hepatic inflammatory gene expression. J Biol Chem 2003, 278:42774-42784.

21. Henninger DD, Gerritsen ME, Granger DN: Low-density lipoprotein receptor knockout mice exhibit exaggerated microvascular responses to inflammatory stimuli. Circ Res 1997, 8I:274-28I.

22. Fleet JC, Clinton SK, Salomon RN, Loppnow H, Libby P: Atherogenic diets enhance endotoxin-stimulated interleukin-I and tumor necrosis factor gene expression in rabbit aortae. J Nutr 1992, I 22:294-305.

23. Brito BE, Romano EL, Grunfeld C: Increased lipopolysaccharideinduced tumour necrosis factor levels and death in hypercholesterolaemic rabbits. Clin Exp Immunol 1995, I 0 I :357-36I.

24. Cerwinka WH, Cheema MH, Granger DN: Hypercholesterolemia alters endotoxin-induced endothelial cell adhesion molecule expression. Shock 200I, 16:44-50.

25. Kim S, Sohn I, Ahn Jl, Lee KH, Lee YS: Hepatic gene expression profiles in a long-term high-fat diet-induced obesity mouse model. Gene 2004, 340:99-109.

26. $\mathrm{Xu} X \mathrm{H}$, Shah $\mathrm{PK}$, Faure $\mathrm{E}$, Equils $\mathrm{O}$, Thomas $L$, Fishbein $M C$ Luthringer D, Xu XP, Rajavashisth TB, Yano J, Kaul S, Arditi M: Tolllike receptor- 4 is expressed by macrophages in murine and human lipid-rich atherosclerotic plaques and upregulated by oxidized LDL. Circulation 2001, 104:3103-3108.

27. Edfeldt K, Swedenborg J, Hansson GK, Yan ZQ: Expression of tolllike receptors in human atherosclerotic lesions: a possible pathway for plaque activation. Circulation 2002, I 05: I I58-I I6I.

28. Kim F, Pham M, Luttrell I, Bannerman DD, Tupper J, Thaler J, Hawn TR, Raines EW, Schwartz MW: Toll Like Receptor-4 Mediates Vascular Inflammation and Insulin Resistance in DietInduced Obesity. Circ Res 2007, I 00:1589-1596.

29. Henry RJ, Chiamori N, Golub OJ, Berkman S: Revised spectrophotometric methods for the determination of glutamic-oxalacetic transaminase, glutamic-pyruvic transaminase, and lactic acid dehydrogenase. Am J Clin Pathol 1960, 34:38I-398.

30. Novitsky TJ, Roslansky PF: Quantification of endotoxin inhibition in serum and plasma using a turbidimetric LAL assay. Prog Clin Biol Res 1985, I 89: I8I-196.

31. Bradford MM: A rapid and sensitive method for the quantitation of microgram quantities of protein utilizing the principle of protein-dye binding. Anal Biochem 1976, 72:248-254.

32. Luna LG: Manual of Histological Staining Methods of the Armed Forces Institute of Pathology. 3rd edition. Edited by: Luna LG. New York, McGraw-Hill, Inc; 1968.

33. Snedecor GW, Cochran WG: Statistical Methods, 7th ed. Ames, IA, lowa State University Press; 1980.

34. Park JY, Seong JK, Paik YK: Proteomic analysis of diet-induced hypercholesterolemic mice. Proteomics 2004, 4:5। 4-523.

35. Costa-Pereira AP, Tininini S, Strobl B, Alonzi T, Schlaak JF, Is'harc H, Gesualdo I, Newman SJ, Kerr IM, Poli V: Mutational switch of an 
IL-6 response to an interferon-gamma-like response. Proc Natl Acad Sci U S A 2002, 99:8043-8047.

36. Musson RA, Morrison DC, Ulevitch RJ: Distribution of endotoxin (lipopolysaccharide) in the tissues of lipopolysaccharideresponsive and -unresponsive mice. Infect Immun 1978, 21:448-457.

37. Matsuura M, Galanos C: Induction of hypersensitivity to endotoxin and tumor necrosis factor by sublethal infection with Salmonella typhimurium. Infect Immun 1990, 58:935-937.

38. Whitman SC, Ravisankar P, Elam H, Daugherty A: Exogenous interferon-gamma enhances atherosclerosis in apolipoprotein EI- mice. Am J Pathol 2000, 157:1819-1824.

39. Fantuzzi G, Dinarello CA: The inflammatory response in interleukin-I beta-deficient mice: comparison with other cytokine-related knock-out mice. J Leukoc Biol 1996, 59:489-493.

40. Bedoui S, Velkoska E, Bozinovski S, Jones JE, Anderson GP, Morris MJ: Unaltered TNF-alpha production by macrophages and monocytes in diet-induced obesity in the rat. J Inflamm (Lond) 2005, 2:2.

4I. de Bont N, Netea MG, Rovers C, Smilde T, Hijmans A, Demacker PN, van der Meer JW, Stalenhoef AF: LPS-induced release of ILIbeta, IL-IRa, IL-6, and TNF-alpha in whole blood from patients with familial hypercholesterolemia: no effect of cholesterol-lowering treatment. J Interferon Cytokine Res 2006, 26:10I-107.

42. Girod WG, Jones SP, Sieber N, Aw TY, Lefer DJ: Effects of hypercholesterolemia on myocardial ischemia-reperfusion injury in LDL receptor-deficient mice. Arterioscler Thromb Vasc Biol 1999, 19:2776-278।.

43. Kainuma M, Fujimoto M, Sekiya N, Tsuneyama K, Cheng C, Takano Y, Terasawa K, Shimada $Y$ : Cholesterol-fed rabbit as a unique model of nonalcoholic, nonobese, non-insulin-resistant fatty liver disease with characteristic fibrosis. J Gastroenterol 2006, 4I:97I-980.

44. Kinugawa K, Shimizu T, Yao A, Kohmoto O, Serizawa T, Takahashi T: Transcriptional regulation of inducible nitric oxide synthase in cultured neonatal rat cardiac myocytes. Circ Res 1997, 81:91I-92I.

45. Baud V, Karin M: Signal transduction by tumor necrosis factor and its relatives. Trends Cell Biol 200I, I I:372-377.

46. Harris HW, Brady SE, Rapp JH: Hepatic endosomal trafficking of lipoprotein-bound endotoxin in rats. J Surg Res 2002, 106:188-195.

47. Feingold KR, Funk JL, Moser AH, Shigenaga JK, Rapp JH, Grunfeld $\mathrm{C}$ : Role for circulating lipoproteins in protection from endotoxin toxicity. Infect Immun 1995, 63:204I-2046.

48. Read TE, Harris HW, Grunfeld C, Feingold KR, Kane JP, Rapp JH: The protective effect of serum lipoproteins against bacterial lipopolysaccharide. Eur Heart J 1993, I 4 Suppl K: 125- 129.

49. Baumberger C, Ulevitch RJ, Dayer JM: Modulation of endotoxic activity of lipopolysaccharide by high-density lipoprotein. Pathobiology | 991, 59:378-383.

50. Pajkrt D, Doran JE, Koster F, Lerch PG, Arnet B, van der Poll T, ten Cate JW, van Deventer SJ: Antiinflammatory effects of reconstituted high-density lipoprotein during human endotoxemia. J Exp Med 1996, 184:160I-1608.

5I. Levine DM, Parker TS, Donnelly TM, Walsh A, Rubin AL: In vivo protection against endotoxin by plasma high density lipoprotein. Proc Natl Acad Sci U S A 1993, 90: 12040-12044.

52. Murch O, Collin M, Hinds CJ, Thiemermann C: Lipoproteins in inflammation and sepsis. I. Basic science. Intensive Care Med 2007, 33:13-24.

53. Cue JI, DiPiro JT, Brunner LI, Doran JE, Blankenship ME, Mansberger $A R$, Hawkins ML: Reconstituted high density lipoprotein inhibits physiologic and tumor necrosis factor alpha responses to lipopolysaccharide in rabbits. Arch Surg 1994, I 29:193-197.

54. Quezado ZM, Natanson C, Banks SM, Alling DW, Koev CA, Danner RL, Elin RJ, Hosseini JM, Parker TS, Levine DM, et al:: Therapeutic trial of reconstituted human high-density lipoprotein in a canine model of gram-negative septic shock. J Pharmacol Exp Ther 1995,

272:604-6II.

55. Harris HW, Grunfeld C, Feingold KR, Rapp JH: Human very low density lipoproteins and chylomicrons can protect against endotoxin-induced death in mice. J Clin Invest 1990, 86:696-702.
56. Berbee JF, van der Hoogt CC, Kleemann R, Schippers EF, Kitchens RL, van Dissel JT, Bakker-Woudenberg IA, Havekes LM, Rensen PC: Apolipoprotein $\mathrm{Cl}$ stimulates the response to lipopolysaccharide and reduces mortality in gram-negative sepsis. Faseb J 2006, 20:2162-2/64.

57. Kontush A, Chapman MJ: Functionally defective high-density lipoprotein: a new therapeutic target at the crossroads of dyslipidemia, inflammation, and atherosclerosis. Pharmacol Rev 2006, 58:342-374.

58. Ashby D, Gamble J, Vadas M, Fidge N, Siggins S, Rye K, Barter PJ: Lack of effect of serum amyloid A (SAA) on the ability of high-density lipoproteins to inhibit endothelial cell adhesion molecule expression. Atherosclerosis 2001, I54:II3-I2I.

59. Thompson PA, Kitchens RL: Native high-density lipoprotein augments monocyte responses to lipopolysaccharide (LPS) by suppressing the inhibitory activity of LPS-binding protein. $J$ Immunol 2006, 177:4880-4887.

60. Bieri JG, Stoewsand GS, Briggs GM, Phillips RW, Woodard JC, Knapka Jj: Report of the American Institute of Nutrition ad hoc Committee on Standards for Nutritional Studies. J Nutr 1977, 107:1340-1348.
Publish with Bio Med Central and every scientist can read your work free of charge

"BioMed Central will be the most significant development for disseminating the results of biomedical research in our lifetime. "

Sir Paul Nurse, Cancer Research UK

Your research papers will be:

- available free of charge to the entire biomedical community

- peer reviewed and published immediately upon acceptance

- cited in PubMed and archived on PubMed Central

- yours - you keep the copyright

Submit your manuscript here:

http://www.biomedcentral.com/info/publishing_adv.asp
BioMedcentral 